Some types of cognitive therapy - such as those used in managing personality disorders and in conditions traditionally seen as suitable for psychoanalytic treatment-are time consuming and require considerable experience and skill. ${ }^{34}$ By contrast, in cases of anxiety, depression, and physical illness cognitive therapy is characteristically brief and focused. It not only addresses current cognitions but also teaches the patient how to deal with these more successfully in the future. Thus, cognitive therapy should have a prophylactic effect, and there is already some evidence that it does. ${ }^{35-37}$ And if cognitive techniques may be successfully acquired by patients they must also be accessible to general practitioners, physicians, and other specialists. They are described in treatment manuals, ${ }^{38}$ and they offer considerable scope for improving communication between doctors and their patients. ${ }^{26}$

Cognitive therapy initially developed empirically from clinical observation. One of the main strengths of the cognitive model, however, is its support and enhancement by experimental research. ${ }^{10-42}$ This convergence of clinical and experimental data is shown well in a recently published handbook of cognitive therapy. ${ }^{26}$ Reliable data of this kind allow therapists to determine the particular cognitive factors associated with defined types of illness and so to develop specific interventions. Several studies that are testing such interventions are in progress. Their success, and the ease with which they can be applied by clinicians who are not specialists in cognitive therapy, will define more clearly the role of cognitive interventions in physical illness.

Senior Lecturer in Psychiatry,

TOM SENSKY

Charing Cross and Westminster Medical School,

West Middlesex University Hospital,

Isleworth,

Middlesex TW7 6AF

1 Feldman E, Mayou R, Hawton K, Ardern M, Smith EBO. Psychiatric disorder in medical inpatients. Qf Med 1987;241:405-12.

Broadhead WE, Kaplan BH, James SA, et al. The epidemiologic evidence for a relationship between social support and health. Am $\mathcal{F}$ Epidemiol 1983;117:521-37.

3 Wise TN, Mann LS, Puscheck E, Dove H, Kiernan K. Factors affecting anxiety and depression in psychiatric consultation patients. Int f Psychiatry Med 1985-6;15:177-84

4 Rosenberg SJ, Peterson RA, Hayes JR, Hatcher J, Headen S. Depression in medical in-patients. Br f Med Psychol 1988;61:245-54.

5 Hawley DJ, Wolfe F. Anxiety and depression in patients with rheumatoid arthritis: a prospective study of 400 patients. F Rheumatol 1988;15:932-41.

6 Ell K, Nishimoto R, Morvay T, Mantell J, Hamovitch M. A longitudinal analysis of psychological adaptation among survivors of cancer. Cancer 1989;63:406-13.
Taylor SE Adjustment to threatening events: a theory of cognitive adaptation. Am Psychol 1983;38:1161-73.

8 Greer S, Morris T, Pettingale KW. Psychological concomitants of breast cancer-effect on outcome. Lancet 1979 ;ii:785-7.

9 Levenson JL, Kay R, Monteferrante J, Herman MV. Denial predicts favourable outcome in unstable angina pectoris. Psychosom Med 1984;46:25-31.

10 Levine J, Warrenburg S, Kerns R, et al. The role of denial in recovery from coronary heart disease. Pychosom Med 1987;49:109-17.

11 Flor $\mathrm{H}$, Turk DC. Chronic back pain and rheumatoid arthritis: predicting pain and disability from cognitive variables. F Behav Med 1988;11:251-65.

12 McFarlane AC, Brooks PM. An analysis of the relationship between psychological morbidity and disease activity in rheumatoid arthritis. I Rheumatol 1988;15:928-31.

13 Smith TW, Peck JR, Milano RA, Ward JR. Cognitive distortion in rheumatoid arthritis: relation to depression and disability. $\mathcal{F}$ Consult Clin Psychol 1988;56:412-6.

14 Revenson TA, Felton BJ. Disability and coping as predictors of psychological adjustment to the

15 Keefe FJ, Brown GK, Wallston KA, Caldwell DS. Coping with rheumatoid arthritis pain: catastrophizing as a maladaptive strategy. Pain 1989;37:51-6.

16 Lefebvre MF. Cognitive distortion and cognitive errors in depressed psychiatric and low back pain patients. I Consult Clin Psychol 1981;49:517-25.

17 Devins GM, Binik Yil, Gorman P, et al. Perceived self-efficacy, outcome expectancies, and negative mood states in end-stage renal disease. 7 Abnorm Psychol 1982;91:241-4.

18 Affleck $G$, Tennen $\mathrm{H}$, Pfeiffer $\mathrm{C}$, Fifield $\mathrm{J}$. Appraisals of control and predictability in adapting to a chronic illness. J Pers Soc Psychol 1987;53:273-9.

19 Wessely SC, Lewis GH. The classification of psychiatric morbidity in a dermatology clinic. $\mathrm{Br} f$ Psychiatry 1989 (in press)

20 Beck AT. Cognitive therapy and the emotional disorders. New York: Meridian, 1976.

21 Dobson KS. A meta-analysis of the efficacy of cognitive therapy for depression. $\mathcal{f}$ Consult Clin Psychol 1989;57:414-9.

22 Turk DC, Meichenbaum D, Genest M. Pain and behavioral medicine: a cognitive-behavioural perspective. New York: Guilford, 1983.

23 Hawton K, Salkovskis PM, Kirk J, Clark DM. Cognitive behaviour therapy for psychiatric problems. Oxford: Oxford University Press, 1989.

24 Moorey S, Greer S. Psychological therapy for patients with cancer: a new approach. Oxford: Heinemann, 1989.

25 Rush AJ. Cognitive approaches to adherence. In: Frances AJ, Hales RE, eds. American Psychiatric Press review of psychiatry, vol 7. Washington: American Psychiatric Press, 1988:627-42.

26 Freeman A, Simon KM, Beutler LE, Arkowitz H, eds. Comprehensive handbook of cognitive therapy. New York: Plenum, 1989.

27 Turner JA, Clancy S. Strategies for coping with chronic low back pain: relationship to pain and disability. Pain 1986;24:355-64.

28 Philips HC. The effects of behavioural treatment on chronic pain. Behav Res Ther 1987;25:365-77

29 Worden JW, Weisman AD. Preventive psychosocial intervention with newly diagnosed cancer patients. Gen Hosp Psychiatry 1984;6:243-9.

30 Tarrier N, Maguire P. Treatment of psychological distress following mastectomy: an initial report. Behav Res Ther 1984;22:81-4.

31 Fishman B, Loscalzo M. Cognitive-behavioural interventions in management of cancer pain: principles and applications. Med Clin North Am 1987;71:271-87.

32 Maes S, Schlosser M. Changing health behaviour outcomes in asthmatic patients: a pilot study. Soc Sci Med 1988;26:359-64.

33 Atkins CJ, Kaplan RM, Timms RM, Reinsch S, Lofback K. Behavioural exercise programmes in the management of chronic obstructive pulmonary disease. F Consult Clin Psychol 1984;52: the manager $591-603$.

34 Beck AT, Freeman A, eds. Cognitive therapy of personality disorders. New York: Guilford (in press)

35 Kovacs M, Rush AJ, Beck AT, et al. Depressed outpatients treated with cognitive therapy or pharmacotherapy. Arch Gen Psychiatry 1981;38:33-9.

36 Blackburn IM, Eunson KM, Bishop S. A two year naturalistic follow up of depressed patients treated with cognitive therapy, pharmacotherapy and a combination of both. $\mathcal{J}$ Affective Disord 1986;10:67-75.

37 Simons AD, Murphy GE, Levine JL, et al. Cognitive therapy and pharmacotherapy for depression sustained improvement over one year. Arch Gen Psychiatry 1986;43:43-8.

38 Beck AT, Rush AJ, Shaw BF, Emery G. Cognitive therapy of depression. New York: Guilford, 1979. 39 Beck AT, Emery G. Anxiety disorders and phobias: a cognitive perspective. New York: Basic Books, 1985.

40 Williams JMG. Cognitive psychology and emotional disorders. Chichester: Wiley, 1988.

41 Brewin CR. Cognitive foundations of clinical psychology. Hove: Lawrence Erlbaum, 1988.

42 Fisher S, Reason J, eds. Handbook of life stress, cognition and health. Chichester: Wiley, 1988.

\title{
Juniors' hours of work
}

\section{eightysomething is too long}

The BMA and the government both agree that junior hospital doctors should work no longer than 72 hours a week. Yet the most recent figures show them contracted for a weekly average of 82 hours.' Given the rare agreement between doctors and the government over such a fundamental condition of service why does such a wide gap persist?

Concentrating on the size of the gap obscures the progress that has been made regarding juniors' hours in recent years. One in one rotas have been outlawed and attempts made to eliminate, firstly, one in two rotas and then rotas more onerous than one in three. Together, these initiatives have brought down the average number of hours worked each week from the upper $80 \mathrm{~s}$ a decade ago. But government circulars and intermittently functioning district working parties are clearly not enough: a survey by regional health authorities showed that last September $22 \%$ of doctors had more onerous rotas than one in three. And despite the exhortations from the Department of Health going back to 1982 many one in two rotas remain.

So what can be done? Three separate solutions could each reduce contracted hours at a stroke. Firstly, the government could turn its long term aim of a 72 hour a week maximum into legislation, and the National Health Service and Community Care Bill, currently before parliament, would seem the ideal vehicle for this. Legislation on shorter hours might have been expected to follow a statement in the government's Self-Governing Hospitals: An Initial Guide that self governing hospitals would be expected "to comply with the Government policy relating to the number of hours for which junior doctors may be employed."' In its current state, however, the 
bill contains no mention of this. Making good this omission is a new clause tabled by the opposition to the bill's report stage, which would inscribe in law the 72 hours a week maximum for NHS trusts. Health ministers have frequently said that this is the government's long term aim $^{3+}:$ it would help its credibility if it was to back the new clause and extend the law to the entire NHS.

Secondly, the Review Body on Doctors' and Dentists' Remuneration could continue its attempts to price long hours out of the reach of employing authorities. In 1988 it fixed penalty rates to hours worked in excess of 104 a week, and in 1989 it reduced that threshold to 96 hours. This year no change was made pending the results of government initiatives. ${ }^{5}$ These were available by the end of last year but apparently were sat on by the Department of Health until after this year's pay awards were made. ${ }^{6} \mathrm{~A}$ similar fate befell Dr Robin Dowie's interim report on junior doctors' hours, which was also relevant to the review body's deliberations. ${ }^{17}$ (The review body's own attempts - through the Office of Manpower Economics - to collect data on junior doctors' hours foundered in part because health authorities' records are so out of date.) Next year the threshold for penalty payments could be reduced to 72 hours a week and if this does not work the size of the penalty could be increased. (Currently it is only twice the value of an " $\mathrm{A}$ " unit of overtime, at most $76 \%$ of the basic rate.)

And finally, the royal colleges and faculties could withdraw their recognition from any post in which the holder is contracted to work more than 72 hours a week, as suggested in the recent meeting of the Hospital Junior Staff Committee ( $p$ 683). Some have argued that rotas at least as arduous as one in three (an 84 hour week) are necessary to fulfil educational and training requirements. But other arguments should see them off - for example, the fatigue induced by an 84 hour week may seriously affect learning, and most countries in the European Community manage to train their specialists without requiring them to work more than 60 hours a week.

Taking any or all of these actions would reduce juniors' hours of work, but the total amount of work that still needed to be done would remain the same. To its credit the government has already set up pilot studies to look at ways of reducing juniors' hours to 72 hours a week. Reports from these, together with reports from regional health authorities on their efforts to reduce rotas more onerous than one in three, suggest many possibilities for improvement.

Juniors' time on duty could be used more efficiently with more cross cover, which would be made easier by amalgamating consultant "firms" into "teams." Introducing a shift svstem would mean that doctors could work harder for shorter periods: intensive care units, neonatal units, and some departments of obstetrics and gynaecology have already mandged this with the added bonus that consistent management poilcies have been drawn up. Sharing workload with othor members of hospital staff-for example, nurses and Initwires, ward clerks, and secretaries-could free junior incin al ift lor genuinely medical work.
Even if these options were fully exploited, however, it seems likely that more junior staff would still need to be appointed. To maintain a balanced career pyramid more consultants would also need to be appointed, which is anyway justified given the continuing evidence that consultants are working, on average, far in excess of their contracts.

Before Easter Mrs Virginia Bottomley, Minister for Health, will be meeting representatives of the royal colleges, the Joint Consultants Committee, the BMA, NHS management, and her own department to discuss the topic. It is of a seriousness to justify the setting up of a ministerial working party (one of the reasons why Achieving a Balance saw the light of day when so many previous plans for medical staffing had failed). ${ }^{8}$ Mrs Bottomley wants all parties concerned to commit themselves formally to a programme of action. If legislation on hours is not included in the NHS bill currently going through parliament then the ultimate goal of this programme of action should be legislation.

Introducing a maximum working week of 72 hours from say 1 April next year would be far too soon given the progress that first needs to be made on devising new working arrangements. But knowing that rotas entailing more than 72 hours a week would be illegal two or three years hence would concentrate the minds of all those concerned wonderfully. If the government were to believe that staggering the introduction of the new hours was necessary then those in the hard pressed specialties and "junior" juniors-the senior house officers - should benefit first.

“Eight hours' work, eight hours' rest, and eight hours' recreation"- the 40 hour week - has been a rallying cry since the middle of the last century, even if it took this country's workers 100 years to achieve it. Today, junior hospital doctors are working on average more than twice that 40 hours. In the circumstances, calling for legislation for a maximum of 72 hours a week seems like a very modest proposal.

Assistant editor, BMJ

TONY DELAMOTHE

1 Bottomley V. Parliamentary written answer. House of Commons official report (Hansard) 1990 Feb 8:166 ( $(\mathrm{col} 770)$ ). (No 47.)

2 Department of Health. Self-governing hospitals: an initial guide. London: HMSO, 1989.

3 Department of Health. David Mellor announces pilot studies to reduce junior doctors' hours. London: DoH, 1989. (89/279 press notice.)

4 Department of Health. Virginia Bottomley invites British Medical Association to talks on junior hospital doctors' hours of work. London: $\mathrm{DoH}, 1989$. (89/574 press notice.)

Review Body on Doctors' and Dentists' Remuneration. Twentieth report 1990. London: HMSO, 1990. (Cmnd 937.)

Bottomley V. Parliamentary written answer. House of Commons official report (Hansard) 1989 Dec 12;163 (col 595). (No 16.)

7 Dowie R. Patterns of hospital medical staffing. Junior doctors' hours. Interim report. London: British Postgraduate Medical Federation, 1990.

Postgraduate Medical Federation, 1990.
United Kingdom Health Departments, Joint Consultants Committee, Chairmen of Regional Health Authorities. Hospital medical staffing: achieving a balance: a plan for action. London: $\mathrm{DoH}, 1987$.

\section{Correction}

Multiple endocrine neoplasia type 2

A printer's error occurred in the box of this editorial by Dr Bruce Ponder (24 February, $p$ 484). The nomenclature for genes is MEN2A, MEN2B, and MEN2 and not MEN 2A, MEN 2B, and MEN 2 as published. 